\title{
A Residential Survey on Urban Tourism Impacts in Harbin
}

\author{
Yu WANG, Gang LI* and Xuemei BAI
}

\begin{abstract}
Tourism is becoming more and more important in the global economy, and its longterm prosperity is desired by every tourism destination. Prosperity, however, cannot be achieved successfully without the involvement of those influenced by the industry, so, evaluating residents' perceptions of tourism and involving them in as many aspects of planning and policymaking as possible are important steps in creating sustainability in tourism destination development. In attempting to fill in the research gaps in social impact analysis of urban tourism development in the Chinese context, a face-to-face survey was carried out to explore residents' perceived impacts of tourism development in Harbin, a famous tourist destination in north-eastern China. The findings of this survey suggest that residents' reaction towards local tourism development varies between different interest groups. Age, income and personal connections with local tourism were found to influence residents' perceptions to some extent.
\end{abstract}

Key Words: Urban tourism, tourism social impacts, residential perceptions, survey, Harbin

${ }^{*}$ Corresponding author, email: g.li@surrey.ac.uk.

Note: This is an author-prepared PDF of an article published in China Tourism Research (2005), Vol. 1(1): 116-129. 


\section{城市旅游对当地居民的影响--哈尔滨实证分析}

\section{王俞＼cjkstart李刚＼cjkstart白雪梅}

\section{内容摘要:}

旅游业现已日渐成为世界经济的重要组成部分。每一个旅游目的地都渴望实现其自身 长期而稳定的繁荣发展，而这一目标的顺利实现不能脱离受旅游业发展影响的各方面利 益群体的参与。因此, 了解旅游地居民对当地旅游业发展所持的观点并及时进行评估 以及尽可能地让他们参与到当地旅游业发展的规划和政策制定过程中是实现旅游目的 地可持续性发展目标的重要步骤。然而, 目前关于旅游业发展的各类影响研究在城市 旅游范畴内还很薄弱。这一点尤其体现在对中国旅游发展影响问题的研究中。为了弥 补这两方面的研究不足, 研究者以中国北方著名的旅游城市哈尔滨为例, 以面对面问 卷调查的方式对旅游业发展给当地居民所带来的影响进行了调查。调查结果表明受调 查者的背景, 尤其是居民的年龄、收入情况以及和当地旅游业的关连性等特点都会不 同程度地影响其对当地旅游业发展所持的观点。

关键词: 城市旅游、社会影响、居民观点、问卷调查、哈尔滨 


\section{Research Background}

The fast worldwide growth of tourism has had an inevitable effect on host perspectives and attitudes towards the industry's development. The intensification is often associated with a variety of negative impacts, which may cultivate an increasingly antagonistic response from local residents towards the tourism industry and tourists (Pearce, Moscardo and Ross 1996). This can then cause undesirable effects by harming the destination's image and reducing the tourist numbers (e.g., Smith 1978). Fortunately, considerable effort has already been made in trying to discover the host's reactions to local tourism development. Special attention has been paid to observing various kinds of tourism impacts in developing countries (Brunt and Courtney 1999), because these countries are always experiencing high tourism growth rates (Singh 1997), which may consequently change local community's perspectives and attitudes towards the industry and tourists over a period of time (Bastias-Perez and Var 1995).

Surprisingly, despite the fact that China is one of the world's largest developing countries and it is estimated by the World Tourism Organization (WTO) to be the number one world tourism destination country in 2020, very little tourism research has been undertaken in China to investigate how well the host can cope with such rapid growth. The dearth of tourism social impact research in China is probably due to its relatively late entry into the world tourism market, which only became possible since 1978. However, the seemingly sheer contrast between Chinese tourism's short history and its present achievements (with round 98 million international visitors and 878 million domestic tourists in 2002) should only be an encouragement for conducting timely tourism impact research in China in response to such unprecedented growth. Furthermore, due to the differences that existed in social structure and environment, studies conducted in other developing countries will not necessarily reflect the situation in China. All those factors are calling for more research attention on the social impacts of tourism development in the Chinese context.

Along with the increasing popularity of short city breaks, urban tourism is becoming increasingly important. However, to some extent, despite its importance in terms of 
generating both economic benefits and tourist arrivals, the study of 'urban tourism' as a distinct area within the tourism field is still in its infancy (Gilbert and Clark 1997). Besides, those findings from outside the urban environment could be misleading due to the potentially different opinions of residents from rural destinations when compared with the opinions of those living in cities (Snaith and Harley 1999). Bearing in mind the lack of research, the Chinese city resort of Harbin was chosen for this residential survey, in attempting to provide more empirical evidence to existing tourism impact findings in an urban environment. At the time that the research was conducted, Harbin was bidding to hold the 21st Olympic Winter Games in 2010. Having correct understanding of local residents' perceptions, trying to obtain their active support, and developing effective tourism policies, all of these make this research necessary and practical for local tourism management and planning.

\section{Research on Tourism Impacts and Residents' Perceptions}

In recent years the impact of tourism on local residents has been a growing area of research, as it has become widely recognized that planners and entrepreneurs must take the views of the host community into account if the industry is to be sustainable in the long term (Allen, Long, Perdue and Kieselbach 1988, Ap and Crompton 1998). There are many reasons to support this view, and most of them are based on a belief that a happy host is more likely to welcome the tourist and consequently generate an atmosphere which is conductive for both increased repeat visitors (LeBlanc 1992) and positive word-of-mouth marketing effect (Pearce 1994). Since tourism ventures benefit from a "happy" environment, knowing what make residents support or turn against tourism is necessary.

In recognition of the critical role that the host community plays in the tourism development process, many attempts have been made to study residents' attitudes and perceptions towards tourism distinguished by different background features of the local communities. Commonly adopted criteria may include socio-demographic characteristics, economic dependence on tourism, type of employment, and place of residence (e.g., Rothman 1978, Pizam 1978, Belisle and Hoy 1980, Ahmed 1986). Not only were differences found from one destination to another, even within the same community, the local's perceptions were found to be significantly diverse across 
a variety of socio-economic and demographic indicators (e.g., Teo 1994, Snaith and Harley 1999). Thus, many have argued that the residents' opinions of the impacts of tourism should not be viewed as homogenous in their support for tourism development (e.g., Mason and Cheyne 2000).

Several models have been developed to help explain the impacts of tourism and their relationship with residents' perceptions. Doxey's 'Irridex model' (Long, Perdue and Allen 1990), Butler's 'destination life cycle theory' (Butler 1980), and Ap's 'social exchange theory' (Ap and Crompton 1993) all offer very useful theoretical bases to understand residents' attitudes towards tourism, although the first two received some criticism for granting certain degrees of homogeneity of attitudes and community reactions to tourism development (e.g., Joppe 1996, Brunt and Courtney 1999).

Recent investigations have suggested that communities have a certain capacity to absorb tourists. If beyond this capacity or threshold, the expansion may result in negative social and environmental impacts and diminishing returns on tourism investments (e.g., Wahab and Pigram 1997). However, research following this concept has not yet given satisfactory answers to questions like "how does one measure the capacity?" Therefore, as Allen and other academics (1988) concluded, the carrying capacity concept has not been implemented successfully. It seems that none of these approaches can be sufficient by themselves in explaining the complicity. To help better understand the reality, those models should be considered as complementary to each other, rather than conflicting approaches when conducting impact studies, since each of them offers insights into the variety of factors that may affect residents' attitudes towards tourism.

It has been argued that among the important macro-trends, the demographic factors, such as population growth, life expectancy and age profile, are vitally important to tourism (Lickorish 1991). Age, as one of the most easily accessible demographic indicators, has shown its power in differentiating residential perceptions. Previous research results show that a breakdown according to age produced the most varied classification of residents' attitudes of research population, especially in urban areas, as in the case of Darwin, Australia (Bastias-Perez and Var's 1995) and in Lankford and Howard's (1994) study of Columbia River Gorge. Therefore in this Harbin 
research, special attention has been paid to comparing the responses from different residential age groups in seeking to generate more targeted information in assisting local tourism authorities' planning decisions. Income level has also been chosen as one of the differentiating criteria for further comparative analysis because of the assumed comparatively high possibility of 'money' influences on opinions of people from developing countries.

\section{Harbin Residential Survey}

\section{Harbin in brief}

This residential survey was conducted in Harbin, a city in the north-eastern part of China. It is the capital of Heilongjiang province and also the largest of the capital cities of China in terms of area. It has a population of above 9 million residents (3 million in the city proper). The city was first established at the end of the $10^{\text {th }}$ century by the Nuzhen people, and they named the area of their settlement "Harbin" meaning "Swan" (Zhao and Li 1999). By the 1920s, Harbin had become a famous international commercial centre in the Far-East with nearly 200,000 foreign residents from over 30 countries. The names of "Paris in the East" and "Moscow in the East" were given to Harbin show its importance and popularity during that period (HTCTM 2000).

Its unique historical background and its distinct natural resources made Harbin a famous tourist destination in China, and it was selected as China's best Tourist City together with other 53 cities in China's first accreditation of this kind. The Songhua River, the second longest river in Heilongjiang Province (2,309 kilometres long), flows through the city and adds beauty as well as facilitating one of most popular tourist activities in summer, the Songhua River cruise. Every winter, Harbin's Ice and Snow Festival draws over a million visitors from home and abroad. Harbin also has China's best ski resort-Yabuli about 200 kilometres east of the city, where the Third Asian Winter Games was held. For the above reasons, Harbin's tourism has developed very fast with an annual growth rate of almost $10 \%$ in the last three years (HTB 2001). In the year 2000, the city received 155,000 international visitors and 9 million domestic tourists, who bought in US\$ 5.8 million and RMB 4 billion (around US\$ 500 million) tourism income respectively (HTB 2001). 


\section{Data collection}

The main aim of this research is to identify the aspects of their lives residents think have been influenced by tourism development and the degree of each influence. Hypothesis has also been made that significant differences would be found among the residents between age groups with regard to their general and specific perceptions towards tourism development's impacts in Harbin.

A face-to-face questionnaire survey was conducted in Harbin between May and June 2002. 290 residents over 18 years of age were contacted. Of these, 232 responded, and the response rate was $80 \%$. The high response rate was helped by the adoption of a face-to-face household survey method. This method was not only useful to limit the probability of respondents' misunderstanding of questionnaire questions through direct communication, but also helpful to achieve a relatively balanced number of respondents from each age group by the control of the researcher.

A preliminary list of measurement items was developed through a review of the relevant literatures regarding tourism impacts and people perceived quality of life (Ap 1992, Pizam 1978, Tomljenovic and Faulkner 2000). Modifications were made to suit the Harbin context. For example, questions were added in to test government's influence (see Table 1 for specific factors included in the questionnaire). The original questionnaire was designed in English. In order to minimize the language and translation biases and mismatches, the questionnaire was translated and revised by three bi-lingual (English and Chinese) speakers. The instrument was then pilot tested using a small sample of twenty Harbin residents. The final questionnaires containing 47 questions (with 36 perceptual statements) were hand-delivered individually to random adults within selected residential areas, close to Harbin's most popular tourist attractions including "Zhaolin Park", "Zhongyang Street", "Stalin Park", and "St. Sophia Church". 
Table 1 Major factors covered in the questionnaire

\begin{tabular}{|c|c|c|}
\hline \multicolumn{2}{|l|}{ Area } & Example \\
\hline \multicolumn{2}{|c|}{ - $\quad$ General background } & $\begin{array}{l}\text { i.e. Gender, age, length of residency, distance from } \\
\text { respondents' home to the nearest tourist attraction, } \\
\text { subjective definition of "tourist", the degree of } \\
\text { encountering with tourists, personal economic reliance on } \\
\text { tourism, and income level. }\end{array}$ \\
\hline \multirow{4}{*}{$\begin{array}{l}\text { Residential } \\
\text { perceptions } \\
\text { towards }\end{array}$} & Economic impacts & e.g. Employment opportunities, cost of living, etc. \\
\hline & $\begin{array}{l}\text { Socio-cultural } \\
\text { impacts }\end{array}$ & $\begin{array}{l}\text { e.g. cultural/citizenship identity, entertainment/recreation } \\
\text { opportunity, quality of public services, and crime, etc. }\end{array}$ \\
\hline & $\begin{array}{l}\text { Environmental } \\
\text { impacts }\end{array}$ & $\begin{array}{l}\text { e.g. litter, noise, damage to/improvement of natural /city } \\
\text { environment, etc. }\end{array}$ \\
\hline & $\begin{array}{l}\text { Tourism policy- } \\
\text { making }\end{array}$ & $\begin{array}{l}\text { e.g. willingness for participating in tourism policy } \\
\text { making }\end{array}$ \\
\hline
\end{tabular}

The survey questionnaire was mainly composed of structured questions. This method is good for achieving straightforward opinions from a wide range of people (Horn and Simmons 2002) and gives a clear idea of residents' perceptions of tourism. It is also convenient for comparison between different subgroups' opinions (i.e. different age and income groups). However, one open-ended question was also used in seeking out broader and/or more specific residential concerns about Harbin tourism.

Thus, the questionnaire used contained three parts:

1) questions concerned with demographic background and the involvement of respondents in tourism, including gender, age, and length of residency, income level, employment history and so on;

2) a battery of 36 statements referring to both positive and negative economic, social, and environmental impacts of tourism development in Harbin. Respondents were asked to indicate the degree of their agreement or disagreement on a five point Likert-type scale (where a score of 1 represents "strongly disagree" and a score of 5, "strongly disagree"). " 0 " has been used to represent "Don't know" to avoid the "filter effect" (Hall 2001);

3) one open-ended question that residents were asked to state whatever they thought about current local tourism development. 


\section{Study Results}

\section{$\underline{\text { In General }}$}

The Statistical Package for the Social Sciences (SPSS) 12.0 was used as the basic software to analyse and interpret collected quantitative data for this study. Answers for the open-ended question were grouped manually by the researcher. The valid sample (232 residents) of the research was made up of roughly half female (112) and half male respondents (120). The mean age of the sample was 44 years ranging from 20 to 83 years old. Over half of respondents had monthly income over RMB1200 (56.9\%). Over half of the respondents lived at their current address more than five years. The findings in general showed a favourable impression of residents towards tourism. Over two-thirds of households did not want to see restrictions on future local tourism development. When asked if the local authorities were making efforts to encourage tourism development, 93\% agreed. Yet it was also interesting to notice that $24 \%$ of respondents stated that they believed tourism advantaged the community only because that government said so. Besides, the length of residency and income level did not seem to affect the strength of positive views held among residents in general.

$85 \%$ of people agreed that tourism increased employment opportunities in the society, but only $66 \%$ of respondents believed tourism brought remarkable economic benefits to Harbin. Respondents were evenly divided in responding to the statement of "tourism economic benefits are overrated", with 35\% agreeing and 34\% disagreeing. $70 \%$ of people agreed that tourism contributed to the greater choices in local shops. It was felt that tourism has not caused increases in the cost of living as residents felt that other factors (e.g. business environment and urbanization), not tourism, were more influential in increasing the cost of living. One-fifth $(20 \%)$ households considered tourism caused traffic congestion, while more than half (56\%) of respondents didn't agree. The environmental degradation, widely identified in such research, has not been regarded as the result of tourism development in Harbin. Contradictorily, over $70 \%$ of respondents believed "tourism contributes to environmental conservation", which may be because of Harbin's industrial city background.

Residents in Harbin regarded tourists as very different from themselves, but instead of negative feelings towards them, they expressed predominantly positive opinions of tourists. Not surprisingly, almost all the respondents thought foreigners were tourists. 
Over $30 \%$ of respondents didn't include "day-trippers" as tourists. These opinions certainly had influenced their judgements of overcrowding, traffic congestion, and cultural impacts caused by tourists. The majority of residents $(80 \%)$ were of the opinion that tourism did not affect their own lifestyles. Neither the majority (75\%) thought tourism undermined the local culture. Contradictorily, four-fifths of respondents had the feeling that tourists enriched Harbin's culture. Over $86 \%$ of residents agreed that "tourism make Harbin become more interesting and exciting". $77 \%$ respondents expressed their willingness to see more tourists. And exactly half of the total respondents declared that they liked international visitors more than domestic tourists because of their "politer" behaviour.

An optional open-ended question was used in the survey questionnaire asking respondents to give free comments on Harbin tourism development, with a view to suggesting explanations for a variety of perceived dimensions of tourism impacts on Harbin by local residents. Answers to this question provided about 120 written comments, which have certainly given researchers a more comprehensive understanding of local attitudes. Overwhelming positive views toward Harbin tourism development again were found here, but citizens also pointed out several unsatisfying aspects and existing problems regarding current tourism development in Harbin, concerning issues like: seasonality, tourism product development, and tourism education. In most comments, in addition to some similar expressions about the benefits which tourism has brought to Harbin, residents voiced an urgent need of improving service quality in tourism-related industries to meet higher-standard requirements from both international and domestic tourists. Though all respondents expressed their support for future Harbin tourism development, some would prefer themselves to be excused from the planning process and concerned about the insufficiency of their tourism-related knowledge. This view was strongly held by older residents.

\section{Comparisons between Different Residential Groups}

The second objective of this study was to investigate to what extent residents' perceptions towards local tourism development varied between different interest groups. Further comparisons have also been conducted. Variables like, age, income 
and employment link have been chosen as some of the main criteria to classify different residential groups.

Adult respondents were divided into four age groups, with the youngest group containing residents between 18 and 29, followed by people aged 30-49, 50-59 and over 60 respectively. After comparison, the linkage between age and residents' perceptions towards general tourism development in Harbin was not clearly represented (i.e. the differences were not statistically significant), since the overwhelmingly supportive opinions were held by residents across all age groups, and older residents were found to share supportive attitudes towards overall tourism development as strong as other groups. However, relatively mixed perceptions were found regarding specific tourism related-issues among different age groups (as indicated in Table 2). Though the differences were limited, some of the results are worth being mentioned here to assist local tourism planning.

The results showed that compared with the other three age groups, the older residents (60 and over) were the least likely to pay special attention to Harbin's tourism development, although they seemed to share similar supportive attitudes toward local tourism development like others (see Table 2), which is slightly surprising considering that this age group may be particularly vulnerable to adverse impacts of tourism due to "the aging process" (e.g. Morgan and Kunkel, 1998). Furthermore, this group's perceptions of tourism were reported likely being influenced by the government' propaganda. This may be explained by the historical built-up 'trust' relationship between people and the Chinese government, which the older generation had experienced during the early stage of the PRC's development. Compared with the middle-aged groups, younger residents in Harbin seemed to be more concerned with the social impact brought about by the local tourism development, which made them hold stronger beliefs that present social values have become more materialistic partially because of tourism development (see Table 2). 
Table 2 Comparison of Harbin residents' perceptions towards tourism

\section{development between age groups}

\begin{tabular}{|c|c|c|c|c|c|}
\hline \multirow[t]{4}{*}{ Statement } & \multicolumn{5}{|c|}{ Mean } \\
\hline & \multicolumn{5}{|c|}{ By Age Groups } \\
\hline & a. 18-29 & b.30-49 & c. 50-59 & d. $60+$ & Overall \\
\hline & $\mathrm{N}=69$ & $\mathrm{~N}=37$ & $\mathrm{~N}=47$ & $\mathrm{~N}=79$ & $\mathrm{~N}=232$ \\
\hline \multicolumn{6}{|l|}{ Some of the positive statements } \\
\hline Tourism makes Harbin more interesting and exciting & 4.26 & 4.22 & 4.32 & 3.99 & 4.17 \\
\hline Harbin residents have greater choices in shops & 3.87 & 4.11 & 3.98 & 3.70 & 3.87 \\
\hline Improves neighbourhood & 3.41 & 3.86 & 3.83 & 3.66 & 3.65 \\
\hline Creates employment opportunities & 4.22 & 4.22 & 4.21 & 3.94 & 4.12 \\
\hline Lots of economic benefits & 3.51 & 3.81 & 3.68 & 3.77 & 3.68 \\
\hline Contributes to natural preservation & 3.39 & 3.41 & 3.19 & 3.38 & 3.35 \\
\hline Improves police/emergency services & 3.13 & 3.35 & 3.38 & 3.30 & 3.28 \\
\hline Improves medical services & 3.12 & 3.22 & 3.34 & 3.03 & 3.15 \\
\hline Tourists enrich the local culture & 4.10 & 4.11 & 4.13 & 3.95 & 4.06 \\
\hline Tourism makes me proud to be Harbin citizen & 3.80 & 3.89 & 4.06 & 3.87 & 3.89 \\
\hline Tourism development advantages Harbin's development & 4.12 & 4.43 & 4.11 & 4.10 & 4.16 \\
\hline More tourists should be encouraged to visit Harbin & 4.38 & 4.68 & 4.36 & 4.28 & 4.39 \\
\hline \multicolumn{6}{|l|}{ Some of the negative statements } \\
\hline Tourists increase litter on our streets & 2.74 & 2.84 & 2.81 & 3.13 & 2.90 \\
\hline Recreational areas are overcrowded & 3.10 & 2.95 & 2.91 & 3.10 & 3.04 \\
\hline Causes traffic congestion & 2.68 & 2.35 & 2.47 & 2.57 & 2.55 \\
\hline Noisier neighbourhood & 2.42 & 2.65 & 2.74 & 2.56 & 2.57 \\
\hline Causes crime/social problems & 2.70 & 2.59 & 2.55 & 2.82 & 2.69 \\
\hline Damages natural environment & 2.71 & 2.86 & 2.64 & 2.84 & 2.76 \\
\hline Excessive concerns about economic gains & $2.67_{b}$ & $3.32_{a}$ & 3.06 & 2.92 & 2.94 \\
\hline Not enough police to cope with tourism related crimes & $2.90^{-}$ & 2.81 & 2.70 & 2.90 & 2.84 \\
\hline Hospitals can not cope & 3.01 & 2.86 & 3.17 & 2.99 & 3.01 \\
\hline Increases costs of living & 2.51 & 2.57 & 2.72 & 2.61 & 2.59 \\
\hline Servicing international tourists undermines local culture & 1.81 & 2.30 & 1.94 & 2.16 & 2.03 \\
\hline Tourists intrude my life style & 1.91 & 2.27 & 2.13 & 2.09 & 2.07 \\
\hline Economic contributions of tourism are overrated & 2.78 & 2.81 & 2.96 & 3.23 & 2.97 \\
\hline I don't care Harbin's tourism development & 1.80 & 1.81 & 1.91 & 2.77 & 2.16 \\
\hline Some of the multi-attitude statements & & & & & \\
\hline I like international tourists more than domestic ones & 3.51 & 3.70 & 3.30 & 3.37 & 3.45 \\
\hline $\begin{array}{l}\text { I believe tourism benefits Harbin only because the } \\
\text { government says so }\end{array}$ & $\underline{2.23} \underline{\mathrm{d}}_{\mathrm{d}}$ & 2.46 & 2.70 & $2.85_{a}$ & 2.57 \\
\hline
\end{tabular}

Notes:

1) Means were based on a 5-point Likert-type scale, where $1=$ strongly disagree; $2=$ disagree; $3=$ either agree or disagree (neutral); 4= agree; $5=$ strongly agree

2) Subscripts indicate that this mean is significantly different from the corresponding mean in the indicated cluster based on Bonferroni post hoc testing (where $\mathrm{p} \leq .05$ ); bolded and italic numbers indicate means that are significantly higher than other three clusters based on Bonferroni post hoc testing (where $\mathrm{p} \leq .05$ ); underlined numbers indicate means that are significantly lower than the other three clusters based on Bonferroni post hoc testing (where $\mathrm{p} \leq .05$ ).

It has always been assumed that people with higher income are more likely to benefit more from tourism development. Although it is not necessarily the case, the findings in this research seemed to support that income level does influence Harbin residents' perceptions on tourism (see Table 3). For example, the lower income group (monthly income less then RMB 800) included in this research has less stronger feeling about tourism's positive influence either on their life or on the local culture compared with 
the higher income group. Also, they are less worried about the capacity of the local police in coping with tourism-related crime. This may be due to the fact that people in this group are less likely to become the targets for burglary.

Table 3 Different income levels' influence on residents' perceptions toward Harbin's tourism

\begin{tabular}{|c|c|c|c|c|}
\hline \multirow[b]{2}{*}{ Statement } & \multicolumn{2}{|c|}{ Mean } & \multirow[b]{2}{*}{ t-value } & \multirow{2}{*}{$\begin{array}{c}\text { Sig. } \\
(\mathrm{p} \leq .05)\end{array}$} \\
\hline & $\begin{array}{l}\text { Below RMB } 800^{*} \\
\approx 18 \% \text { respondents }\end{array}$ & $\begin{array}{l}\text { RMB } 801 \text { over* } \\
\approx 82 \% \text { respondents }\end{array}$ & & \\
\hline $\begin{array}{l}\text { Tourism makes Harbin more interesting and } \\
\text { exciting }\end{array}$ & 3.78 & 4.26 & 3.142 & .002 \\
\hline $\begin{array}{l}\text { Not enough police to cope with tourism } \\
\text { related crimes }\end{array}$ & 2.41 & 2.94 & 2.553 & .011 \\
\hline Tourists enrich the local culture & 3.78 & 4.12 & 2.213 & .028 \\
\hline
\end{tabular}

(*Note: Income level here refers to the respondent's monthly income range.)

One of the few relatively consistent findings in the area of residents' perception of tourism is that residents who derive financial benefit from the industry tend to hold more positive opinions of it (e.g. Ap 1992). The result in this research seemed have supported this assumption to a certain extent (see Table 3), although the design of this research has not been able to clarify whether such positive tendencies are explainable by the social exchange theory, which assumes that people in such a position may trade off negative impacts against pecuniary gains. Either way, respondents in this research who themselves, or those having relatives currently working in tourism-related industries, tended to possess more positive attitudes towards Harbin's tourism development than those who are not. Understandably, those who have employment links with the industry have stronger beliefs about the economic benefits of tourism development, especially in terms of creating employment opportunities. Unsurprisingly, this may also help to explain why they have sung higher praise for the tourism industry and given more attention to its development (as shown in Table 4). 
Table 4 Current employment link with the tourism industry and its influence on respondents' perceptions on the local tourism's development impact

\begin{tabular}{|c|c|c|c|c|c|c|}
\hline Statement & $\begin{array}{l}\text { The re } \\
\text { wor }\end{array}$ & $\begin{array}{l}\text { spondent /his } \\
\text { king in the to }\end{array}$ & $\begin{array}{l}\text { n } \\
\text { ive(s) } \\
\text { n relate }\end{array}$ & $\begin{array}{l}\text { is/are currently } \\
\text { industries }\end{array}$ & t-value & $\begin{array}{c}\text { Sig. } \\
(\mathrm{p} \leq .05)\end{array}$ \\
\hline $\begin{array}{l}\text { Tourism makes Harbin more interesting and } \\
\text { exciting }\end{array}$ & & 4.33 & & 4.07 & 2.058 & .041 \\
\hline Lots of economic benefits & & 3.85 & & 3.57 & 1.999 & .047 \\
\hline Tourism makes me proud to be Harbin citizen & & 4.05 & & 3.79 & 1.983 & .049 \\
\hline I don't care Harbin's tourism development & & 1.85 & & 2.36 & -3.301 & .001 \\
\hline
\end{tabular}

\section{Discussion of Findings}

Tourism is generally considered as having lifted the quality of life of local residents in Harbin, though only to a moderate degree. This positive opinion may change over time with further tourism development, as a higher influx of tourists could create more friction. As most respondents could not distinguish domestic tourists from unknown locals, some common problems occurred in urban areas, like traffic congestion and rising prices, although these have not been regarded as the side-effects of tourism development. Neither have the local residents perceived any intrusion to the local culture because of tourism development. This may be attributed to the fact that Harbin itself is a "fusion" of many cultures with its local community composed of more than 40 local ethnic groups. Therefore, perhaps, further research would be helpful to reveal whether responses to the factors examined in this research remain static or change over time in responding to the increase in tourism activities.

Few respondents perceived that tourism development has influenced the quality of health care or other social services in Harbin. This may be a reflection that residents were not quite satisfied with the speed in improvements of local public medical and police services. But further analysis of the answers to the open-ended question suggested that this result might also due to the unawareness of respondents about the "spin-offs" effects which tourism may have on social services. A lack of knowledge of 'tourism' in general, together with limited public access to the local tourism development information, may also explain the fact that a noticeable number of respondents chose “don't know” to certain questions. 
Public leisure gardens in China are not so common as in most developed countries. Construction of gardens has been heavily limited by local economic conditions. This shortage is serious in urban areas since land can be "expensive" there. In open comments, older residents expressed their need for more green fields and public gardens around residential districts. As currently more than 9\% of Harbin's population is over 60 and another $9 \%$ are aged between 50 and 59, such need should be given attention in order to create a "happier" host community. Also, as senior citizens were more reluctant to be involved in tourism policy-making, there is a challenge for local planners about how to reflect the needs of this "silent group" in their tourism development plans.

\section{Concluding Remarks}

This research is taken in response to the calls for timely tourism impact research in China and in urban scenarios. While a 'one-shot' study, this research provides valuable information for establishing baseline data of tourism impacts in Harbin through residents' point of view. Through the analysis of tendencies within different interest groups, especially by focusing on their age and income features, it provides an insight into the structure of community reactions to tourism, which enables more effectively targeted remedial or development actions aiming at increasing tourism benefits to the host community. However, the contribution of this research is better viewed as a wake-up call for more well designed tourism social impact research in China. As experienced in many tourism developing countries, the negative impacts of tourism can always be overlooked under its "glorious" cover of economic benefits. In the long-term, an ongoing assessment and continuously evaluation of tourism impacts on a given tourist destination and its community with plural theoretical approaches is desirable to cope with the diversity in reality. Most importantly, there is a necessity to improve the cooperation between academic researchers and tourism planners in order to transfer relevant research findings into the subsequent phrases of tourism planning. 


\section{References}

Ahmed, S. (1986). Understanding residents' reaction to tourism marketing strategies. Journal of Travel Research 25:13-18

Allen, L.R., P. T. Long, R. R. Perdue and S. Kieselbach (1988). The Impact of Tourism Development on Residents' Perceptions of Community Life. Journal of Travel Research, 27(1), 16-21.

Ap, J and J.L. Crompton (1993). Residents' Strategies for Responding to Tourism Impacts. Journal of Travel Research, 32 (1), 47-50.

Ap, J. (1992). Residents' Perceptions of Tourism Impacts. Annals of Tourism Research, 19, 665-690.

Ap, J., and J. L. Crompton (1998). Developing and Testing a Tourism Impact Scale. Journal of Travel Research, 37(2), 120-130.

Ashworth, G. J. (1989). Urban Tourism: An Imbalance in Attention, in C.P. Cooper (eds.), Progress in Tourism, Recreation and Hospitality Management, Belhaven, London.

Bastias-Perez, P. and T. Var (1995). Perceived Impacts of Tourism by ResidentsResearch Notes and Reports. Annals of Tourism Research, 22 (1), 208-209.

Belisle, J. and D. Hoy (1980). The Perceived Impact of Tourism by Residents: A Case Study in Santa Marta. Annals of Tourism Research, 7, 83-99.

Brayley, R., P.S. Sheldonand and T. Var (1990). Perceived Influence of Tourism on Social Issues. Annals of Tourism Research, 17, 285-289.

Brunt, P. and P. Courtney (1999). Host Perceptions of Socio-Cultural Impacts. Annals of Tourism Research, 26 (3), 493-515.

Butler, R. W. (1980). The Concept of a Tourism Area Cycle of Evolution: Implications for the Management of Resources. Canadian Geographer, 24, 512.

CNTA. 2000-2003. The Yearbook of China Tourism Statistics, China National Tourism Administration, Beijing.

Davis, D., J. Allen and R.M. Cosenza (1988). Segmenting Local Residents by Their Attitudes Interests and Opinions toward Tourism. Journal of Travel Research, $27(2), 2-8$.

Fredline, E and B. Faulkner (2000). Host Community Reactions-A Cluster Analysis. Annals of Tourism Research, 27 (3), 763-784.

Gilbert, D. and M. Clark (1997). An Exploratory Examination of Urban Tourism Impact with Reference to Residents Attitudes in the Cities of Canterbury and Guildford. Cities, 14 (6), 343-352.

Hall, C. M. (1994). Tourism and Politics, Policy, Power and Place, John Wiley: Chichester:

Hall, T.E. (2001). Opinion Filter in Recreation Research: the Effect of Including "No Opinion" and "Not Notice" Response Categories in Questionnaires. Tourism Analysis, 6, 1-15. 
Horn, C. and D. Simmons (2002). Community Adaptation to Tourism: Comparisons between Rotorua and Kaikoura, New Zealand. Tourism Management, 23, 133-143.

HTB (2001). The Tenth Five-year Plan of the Tourism Development of Harbin City, Harbin Tourism Bureau, Harbin.

HTCTM (2000). Harbin Tourist \& Commercial Traffic Map, Harbin Cartographic Publishing House, Harbin.

Joppe, M. (1996). Sustainable Community Tourism Development Revisited. Tourism Management, 17, 475-479.

Lankford, S.V. and D. R. Howard (1994). Developing a Tourism Impact Attitude Scale. Annals of Tourism Research, 21, 121-139.

LeBlanc, G. (1992). Factors Affecting Customer Evaluations of Service Quality in Travel Agencies: An Investigation of Customer Perspectives. Journal of Travel Research, 30, 10-16.

Lickorish, L.J. (1991). Developing Tourism Destinations-Policies and Perspectives, Longman, Essex.

Long, P., R. Perdue and L. Allen (1990). Rural Resident Tourism Perceptions and Attitudes by Community Level of Tourism. Journal of Travel Research, 28 (3), 32- 44.

Mason, P. and J. Cheyne (2000). Residents' Attitudes to Proposed Tourism Development. Annals of Tourism Research, 27 (2), 391-411.

Morgan, L. and Kunkel, S. (1998). Aging-the Social Context, Pine Forge Press, London.

Pearce, P. L. (1994). Tourist-Resident Impacts: Examples, Explanations and Emerging Solutions, in W. Theobald (eds.), Global Tourism: the Next Decade, , Butterworth Heinemann, Oxford

Pearce, P. L.; G. Moscardo and G. F. Ross. (1996). Tourism Community Relationships, Pergamon Press Ltd, London.

Perdue, R.; P. Long and L. Allen (1990). Resident Support for Tourism Development. Annals of Tourism Research, 17 (4), 586-599.

Pizam, A. (1978). Tourism Impact: the Social Cost to Destination Community as Perceived by Its Residents. Journal of Travel Research, 16, 8-12.

Rothman, R. (1978). Residents and Transients: Community Reaction to Seasonal Visitors. Journal of Travel Research, 16, 8-13.

Singh, S. (1997). Developing Human Resources for the Tourism Industry with Reference to India. Tourism Management, 18 (5), 299-306.

Smith, V. 1978. Host and Guests: the Anthropology of Tourism, Blackwell, Oxford.

Snaith, T and A. Haley (1999). Residents' Opinions of Tourism Development in the Historic City of York, England. Tourism Management, 20: 595-603.

Teo, P. (1994). Managing Socio-Cultural Impacts: the Case of Singapore. Tourism Management, 15 (2), 126-136. 
Tomljenovic, R. and B. Faulkner (2000). Tourism and Older Residents in a Sunbelt Resort. Annals of Tourism Research, 27(1), 93-114.

Wahab, S. and J J. Pigram (1997). Tourism, Development and Growth: the Challenge of Sustainability, Routledge, London..

Weaver, D. and L. J. Lawton (2004). Visitor Attitudes toward Tourism Development and Product Integration in an Australian Urban-rural Fringe. Journal of Travel Research, 42, 286-296.

Zhao, X.L. and X. Y. Li. (1999). Guide to Heilongjiang China, Heilongjiang People's Publishing House, Harbin, China. 